\title{
A Camisola do Dia. Patrimônio têxtil da cultura material nupcial (Rio Grande do Sul, do início a meados do século XX)
}

\section{The Camisola do Dia: Textile heritage and wedding material culture (Rio Grande do Sul, from beginning to mid XXth Century \\ Fábio Vergara Cerqueira Denise Ondina Marroni dos Santos}

\section{A camisola do dia $e$ a cultura material}

A camisola do dia era uma peça do vestuário feita especialmente para o enxoval, usada em várias regiões do Brasil entre o final do século XIX e a década

O artigo é baseado no estudo realizado para a curadoria e a organização da exposição $A$ Camisola do Dia. Memórias da Noite de Núpcias, bem como para subsidiar o respectivo catálogo. A exposição foi levada a público em 2008 e 2009, nas cidades gaúchas de Pelotas, Jaguarão e Arroio Grande.

Fábio Vergara Cerqueira é doutor em Antropologia Social pela Universidade de São Paulo (USP) e professor do mestrado em Memória Social e Patrimônio Cultural e do mestrado em História da Universidade Federal de Pelotas (UFPEL), Pelotas, Brasil (fabiovergara@uol.com.br).

Denise Ondina Marroni dos Santos é mestre em Memória Social e Patrimônio Cultural pela Universidade Federal de Pelotas, Pelotas, Brasil (denimarroni@hotmail.com).

Artigo recebido em 30 de junho de 2011 e aprovado para publicação em 20 de setembro de 2011. 
de 1960. Em sua materialidade física e em sua imaterialidade simbólica, constitui um componente da cultura material. E de uma expressão específica: a "cultura material nupcial", parte integrante do ritual de núpcias da sociedade cristã ocidental moderna (Figuras 1 e 2).

Figura 1 e Figura 2

Exposição "A Camisola do Dia. Memórias da Noite de Núpcias”.

Museu Municipal Parque da Baronesa, Pelotas, dezembro de 2008 (fig. 1)

Instituto João Simões Lopes Neto, Pelotas, maio de 2009 (fig. 2)
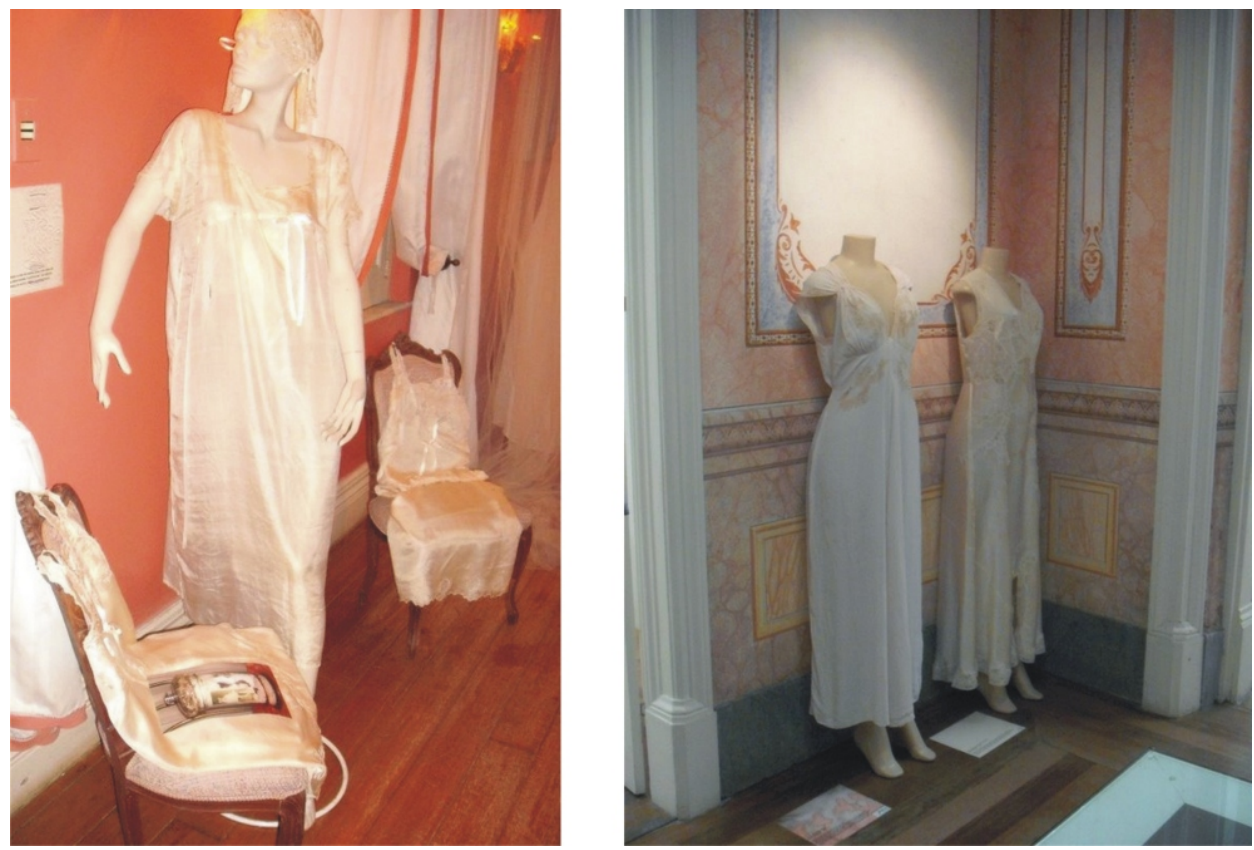

A cultura material é uma perspectiva de investigação originada na disciplina arqueológica, açambarcando "toda e qualquer coisa que tenha sido produzida materialmente pelo homem para satisfazer suas necessidades básicas". Engloba, assim, esferas tão variadas quanto "a moradia, a produção de alimentos, a religiosidade, o lazer, a educação, a locomoção" (Peixoto, 2008: 88).

De certo modo, o reencontro da disciplina histórica com a cultura material traça uma espécie de retorno às raízes. Como lembra Funari (2005: 84) - remetendo-nos à escrita de historiadores da Antiguidade, como Heródoto, Tucídides e Salústio -, a história se fazia "com testemunhos, com objetos, com paisa- 
gens, não necessariamente com documentos escritos, consultados apenas marginalmente e citados de forma indiretamente reportada".

Porém, o que está em jogo é mais do que isso, uma vez que os objetos nos permitem acessar dimensões da vivência social e cultural que não são articuláveis e comunicáveis pela linguagem escrita e até mesmo oral. A esse respeito, Radley (1992: 63) assevera que

A ênfase na linguagem tende a ocultar perguntas interessantes que emergem quando reconhecemos que a esfera dos objetos está ordenada em formas de que dependemos para conseguir um sentido de continuidade e como marcadores temporais.

Ou seja, os artefatos alinhavam o cotidiano, dando uma coesão de sentido, posicionando a percepção de pertença ao tempo, a uma geração, a uma época, a um conjunto de códigos culturais que funcionam, ao mesmo tempo, como marcadores de identidade. É possível, através dos objetos, descobrirem-se redes de significados responsáveis por amarrar os sentidos que articulam a vida social e, ao mesmo tempo, informam a nós, pesquisadores, sobre o modo de vida das pessoas no passado e no presente (Cerqueira, 2006: 4). Desse modo, os objetos são uma "fonte primária de observação aberta à exploração. Neles se condensa um amplo leque de manifestações e relações humanas, tanto existidas como existentes" (Gruneberg, 2000: 167).

Trabalhar com cultura material convida-nos a incorporar a perspectiva da arqueologia histórica pós-processual, pela qual se busca construir uma visão êmica do passado, construindo interpretações sustentadas sobre testemunhos os mais múltiplos (Orser, 2006: 106). Não obstante se defina como a totalidade material transformada e consumida pela sociedade (Funari, 1988; Muniz, 1988), a cultura material inclui muito mais do que a concretude física do material, pois carrega consigo sua imaterialidade.

Concretamente, a cultura material compõe-se de todo o conjunto de artefatos - ou seja, de instrumentos materiais produzidos pelo homem a partir da transformação de elementos naturais - e pode ser móvel ou imóvel. Os bens materiais móveis são os objetos ou utensílios, como a camisola do dia; os bens imóveis são as estruturas, como as igrejas, as casas. Essa materialidade, porém, não é somente material:

Nesta materialidade, estão imbricados os aspectos simbólicos e pragmáticos da cultura. Ou seja, os objetos carregam consigo, ao mesmo tempo, a sua dimensão prática (a sua finalidade de uso) e a sua 
dimensão simbólica (o conjunto de valores, princípios éticos, padrões de comportamento, etc.), associadas a estes objetos, na sua fabricação e no seu consumo (Peixoto, 2008: 88).

Dessa forma, a camisola do dia - esta singela peça da "cultura material matrimonial", que poderíamos considerar o item mais elaborado de todo o enxoval do ponto de vista artefactual e simbólico - carrega consigo mais do que um exemplo de refinamento, de investimento cultural e financeiro: carrega um conjunto de significações. Talvez mais eficiente do que muitos documentos escritos, permite-nos compreender não somente a instituição do casamento na sociedade brasileira do final do século XIX até os anos 1960, como também as representações e expectativas relativas ao feminino.

Para propormos nossa compreensão dessa expressão de cultura material, precisaremos articular diferentes dimensões: a representação literária de simbolismos associados às núpcias; a caracterização física e técnica do bem cultural; o saber fazer das bordadeiras; os significados da camisola na memória, conservados no registro da oralidade; a dimensão histórica do casamento; e o viés patrimonial da camisola do dia como um representante do chamado patrimônio têxtil, constituído pelas peças de indumentária (cf. Santos, 2009).

\section{A instituição da camisola do dia e a memória da noite de núpcias}

As camisolas do dia, peças do enxoval que se destinavam, em décadas passadas, à primeira noite do casal, hoje conservadas em cantos dos roupeiros, remetem-nos a um passado próximo de nós, do ponto de vista cronológico, ainda que distante no que concerne à mentalidade. $\mathrm{O}$ enorme distanciamento de um item da cultura material de um passado tão próximo, como a camisola do dia, fala-nos da acelerada secularização do mundo contemporâneo, em que expressões de sacralidade íntima, oriundas de instituições sociais bastante antigas, como a exigência de virgindade, se mantinham vigentes até poucas décadas atrás.

Admirar a beleza dos tecidos e sofisticação dos bordados, a fineza dessas peças nupciais, e observar o quanto representam conceitos de família e casamento distanciados dos padrões de relacionamento conjugal contemporâneos, significa olharmos para o fundo da psicologia social de um tempo recente, evocando os sentimentos íntimos e as expectativas de felicidade da época de juventude de nossas mães e avós.

Ao estudarmos a camisola do dia, feita expressamente para a noite de núpcias, propomos uma reflexão sobre as sensibilidades femininas e as projeções da sociedade sobre a instituição do casamento. Ao mesmo tempo, trata- 
mos essa peça especial do enxoval como um suporte de memória privilegiado, pois carrega consigo o simbolismo de valores estruturantes das sociedades ocidentais do passado recente, constituindo, paralelamente, um registro do primoroso saber fazer das "bordadeiras especiais" de enxovais, ofício feminino que perdeu espaço diante do avanço da industrialização no setor de confecções a partir dos anos 1960.

Para compreendermos esta "instituição social" que foi a camisola do dia (Teixeira, 2004: 286), ${ }^{1}$ procuramos investigar sua dimensão cultural, através da análise antropológica de seu simbolismo, da interpretação de seu lugar na memória social e da caracterização do saber fazer das bordadeiras, familiares da noiva ou profissionais. Consideramos essas peças exemplos paradigmáticos da "cultura material matrimonial". Com base em depoimentos e no estudo de uma mostra representativa de exemplares conservados, nos deteremos com mais atenção na sociedade do Rio Grande do Sul, de início do século XX até os anos 19601970.

Ademais, ao tratarmos a camisola do dia enquanto elemento de memória social, procuraremos nos aproximar dela por meio de diversos suportes de memória, que incluem, além dos registros fotográficos, ${ }^{2}$ os testemunhos orais e até mesmo abordagens do tema na linguagem literária, em três gêneros de expressão: a canção, a poesia e a prosa. Selecionamos, assim, textos representativos de uma extensão cronológica de quase três décadas (1931-1957), de autoria de Pedro Wayne, Gabriel García Márquez e Herivelto Martins.

Desse modo, alçamos essa peça íntima feminina à categoria de patrimônio cultural, considerando-a expressão tanto do patrimônio tangível quanto intangível, trazendo consigo o saber fazer e os valores subjetivos da moralidade familiar ocidental, adaptados à sociedade brasileira dos seis primeiros decênios do século XX.

\section{A camisola do dia $e$ a noite de núpcias na literatura}

Um dos testemunhos da impregnação da instituição social da camisola do dia no período foram suas representações na literatura e na música, na poesia e na prosa. A capacidade da literatura para criar a atmosfera de sentimentos subjetivos que atormentavam a psicologia da noiva na primeira noite de núpcias, no mundo cristão ocidental, está bem configurada em um trecho do primeiro romance de Gabriel García Márquez, publicado em 1955, sob o título original La Hojarasca, e conhecido pelo leitor brasileiro como $A$ revoada: o enterro do diabo: 
Tirei o meu vestido de noiva, embrulhei-o e guardei no fundo do armário [...] Martín sentou-se ao meu lado e ficamos um momento sem falar. Pela primeira vez desde meu nascimento tive medo que anoitecesse, e devo tê-lo manifestado de alguma forma, porque repentinamente Martin pareceu viver. Inclinou-se sobre meu ombro e disse: "Em que está pensando?" Senti que alguma coisa se torcia no meu coração: $o$ desconhecido começava a me tratar com intimidade. ${ }^{3}$

Ao analisarmos os depoimentos orais e as memórias evocadas do uso da camisola do dia, veremos certa convergência com o sentimento que a noiva do romance de García Márquez traz diante das núpcias, presente nas expressões "tive medo que anoitecesse" e "o desconhecido começava a me tratar com intimidade".

Em um ambiente cultural bastante diferente de García Márquez, o lamento amoroso do samba foi capaz de figurar a atmosfera mágica que o imaginário da camisola do dia carregava. O "divino conteúdo", predicado que lhe atribuem os versos de Herivelto Martins, pode ser interpretado como uma metáfora do sagrado, uma vez que a cor suave da camisola remete à pureza da noiva que se pressupõe virgem, na qual estão implicados valores religiosos e sociais de forte adesão na sociedade da época. Estávamos em 1957, quando Herivelto Martins e Davi Nasser ${ }^{4}$ trouxeram a público a canção $A$ Camisola do Dia, interpretada por sua ex-esposa e parceira musical, Dalva de Oliveira, e consagrada pela voz de Nélson Gonçalves, cujos versos reproduzimos abaixo:

\section{A CAMISOLA DO DIA}

Amor, eu me lembro ainda

Era linda, muito linda

Um céu azul de organdi

A camisola do dia

Tão transparente e macia

Que eu dei de presente a ti

Tinha rendas de Sevilha

A pequena maravilha

Que o teu corpinho abrigava

E eu era o dono de tudo

Do divino conteúdo

Que a camisola ocultava 
A camisola que um dia

Guardou a minha alegria

Desbotou, perdeu a cor

Abandonada no leito

Que nunca mais foi desfeito

Pelas vigílias de amor ${ }^{5}$

Duas décadas antes de García Márquez e Herivelto Martins, o poeta bageense Pedro Wayne ${ }^{6}$ cantou em verso o ambiente "sagrado" da "primeira noite", em que a pureza da noiva virgem estava simbolizada por sua camisola do dia, que ele representou por meio da imagem "paramentada de branco". Estávamos na Bagé de 1931, em que o recato da noiva no interior de sua camisola, signo de sua dignidade, aparecia na poesia de Wayne por meio da metáfora "no cálice dourado de tua timidez". A timidez, aqui, é virtuosa. Reproduzimos aqui os versos do poema "Primeira Noite", parte da coletânea Versos Meninósos e a Lua:

\section{PRIMEIRA NOITE}

\section{Paramentada de branco}

$\mathrm{Na}$ catedral silenciosa de nosso quarto, no cálice dourado de tua timidez;

eras bem a eucaristia sagrada

em que na missa festiva

da consagração de nossos sonhos

meu sangue e minha carne tomariam formas ... 7

Os registros literários ficcionais - sejam eles da poesia ou da prosa, ou até mesmo do samba - constituem importantes suportes de memória, evocativos dos sentimentos e sensações que integram a rede de significados que compõe a cultura material, inclusive pela capacidade que a criatividade literária possui de nos reportar às sensações e aos sentimentos vividos no cotidiano em que se dá o uso dos objetos.

A diferença de um quartel de século permite perceber pequenas mudanças de costumes: no poema de 1931, depreende-se que a camisola do dia era branca, signo da virgindade; na canção de 1957, supõe-se que fosse azul, cor que, segundo o discurso mais tradicional, não seria permitida no primeiro dia. Mudança de costumes, talvez liberalidade da capital federal, do Rio de Janeiro; talvez comportamento mais permissivo de artistas. O fato é que Herivelto chega a mencionar que teria presenteado a noiva com a camisola, costume que vai de encontro ao que co- 
locam os depoimentos orais que registramos em nossa pesquisa, pois a camisola não poderia ter sido vista ou tocada anteriormente pelo noivo, devendo ser providenciada pela família da noiva e sendo, pois, parte de seu enxoval.

Podemos dizer que os artefatos, as coisas, bem como suas representações imagéticas e simbólicas (aqui compreendidas as representações poéticas ou prosaicas), "circulam nas entranhas das memórias dos sujeitos sociais, em meio a sentimentos e vivências que sustentam vínculos com seus lugares de pertencimento" (Silveira, 2008: 19-20). Assim, também na literatura, enquanto suporte de memória, ocorre a articulação entre a dimensão objetiva da cultura material e suas dimensões subjetivas, que se condensam nas memórias individuais e coletivas:

Essa articulação se dá, pois os objetos, sons ou aromas dinamizam a memória coletiva ou individual e constituem manifestações da materialidade da cultura de um grupo social, desencadeando tensões entre as reminiscências e o esquecimento (Funari \& Pelegrini, 2007: 5).

O samba $A$ Camisola do Dia exemplifica essa articulação entre o objeto e a memória no texto ficcional literário. A canção de Herivelto Martins caracteriza-se por ser uma narrativa memorial, em que o objeto lembrado (a camisola) mistura-se com a lembrança dos bons tempos vividos do amor correspondido, $\mathrm{e}$ o afastamento temporal do objeto, seu desgaste e a perda de sua cor remetem ao amor que se foi. A cor desbotada é a própria tensão entre reminiscência e esquecimento, ressaltada por Funari e Pelegrini. Por meio dessa narrativa memorial, evoca sensações que permeavam a instituição social da camisola do dia, mitificadas como o "divino conteúdo".

\section{O saber fazer, os tecidos, as técnicas e seus significados ${ }^{8}$}

Os "significados" das roupas são "construções" colocadas sobre elas, e não podem ser lidos num dicionário, como podem os significados verbais. Esses significados baseiam-se na percepção de escolhas específicas [...] no que diz respeito a tecido, cor, corte, [...] qualquer significado na roupa será corroborado ou modificado pela postura $\mathrm{e}$ movimento do corpo dentro dela (Harvey, 2003: 15).

A criação da agulha de mão foi considerada por James Laver (1999: 10) um dos maiores avanços tecnológicos da humanidade, podendo ser compara- 
da, em importância, à invenção da roda e à descoberta do fogo. Encontrados em cavernas paleolíticas, esses objetos produzidos para costurar peles a fim de conformá-las ao corpo, datam de 40 mil anos e foram esculpidas em ossos, marfim ou presas de leão-marinho. De lá para cá, técnicas que se utilizavam de fibras animais e vegetais foram desenvolvidas para a produção de tecidos, bem como meios de amoldá-los ao corpo a fim de cobrir e guardar. A manufatura de tecidos - artesanal, a princípio e, posteriormente, em escala industrial - teria sido, então, o primeiro passo para o desenvolvimento do vestuário tal qual o concebemos atualmente.

O tecido cobre, vela, resguarda e aconchega. Produz sensações. Pode repelir. Na intimidade, mostra-se adornado, sedoso e atraente, moldando delicadamente o corpo que finge cobrir, enquanto o que mais consegue é revelar. A roupa traz consigo uma espécie de jogo dialético entre o que e quando ocultar ou mostrar. ${ }^{9}$

Como um convite rebuscado ao toque, as peças íntimas da noite de núpcias requeriam uma seleção dos materiais que iriam compor o traje, não raro apresentado em duas ou quatro peças (camisola e robe de chambre ou camisola, robe de chambre, soutien ${ }^{10} \mathrm{e}$ calcinha). Quando feitas sob medida, a escolha da fazenda geralmente se dava em companhia e esta etapa consistia num ritual executado por mães, irmãs e tias, colaboradoras na avaliação do material. Utilizavam-se do toque com o fim de experimentar a textura, a qualidade da fazenda e de compará-las a outras peças, resultando assim na primeira escolha para a confecção do conjunto. A preferência por tecidos maleáveis e sedosos deve-se primeiramente ao conforto e à agradável sensação destes quando em contato com a pele. Entretanto, outro elemento, a sedução, se utilizava desses artifícios a fim de atrair o parceiro naquela ocasião em que as intimidades se aprofundariam, dando início à vivência sexual do casal.

O corpo a ser vislumbrado - coberto de rendas estrategicamente colocadas ou de delicados adornos bordados (cf. Figura 5-detalhe), que sugeriam a pureza da nubente - era o destaque para onde o olhar do parceiro convergia. Insinuar é mais do que revelar. Captar o olhar e entrelaçá-lo era o fim único e, por isso, a produção dessas peças requeria atenção especial. Em muitos casos, eram talhadas e executadas por habilidosas costureiras (cf. Figuras 4 e 5), de posição privilegiada perante outras profissionais, das quais as mais "afamadas" também eram as mais procuradas. Havia, porém, quem as confeccionasse em casa (Figura 3). Dessas, vale salientar as moças prendadas, bordadeiras ou mesmo alguma parenta da noiva, as quais se encarregavam muitas vezes do cosimento, bordados e arremates da peça, bem como do próprio enxoval. É o caso da camisola do dia da senhora Marly Dilli Loges. 


\section{Figura 3}

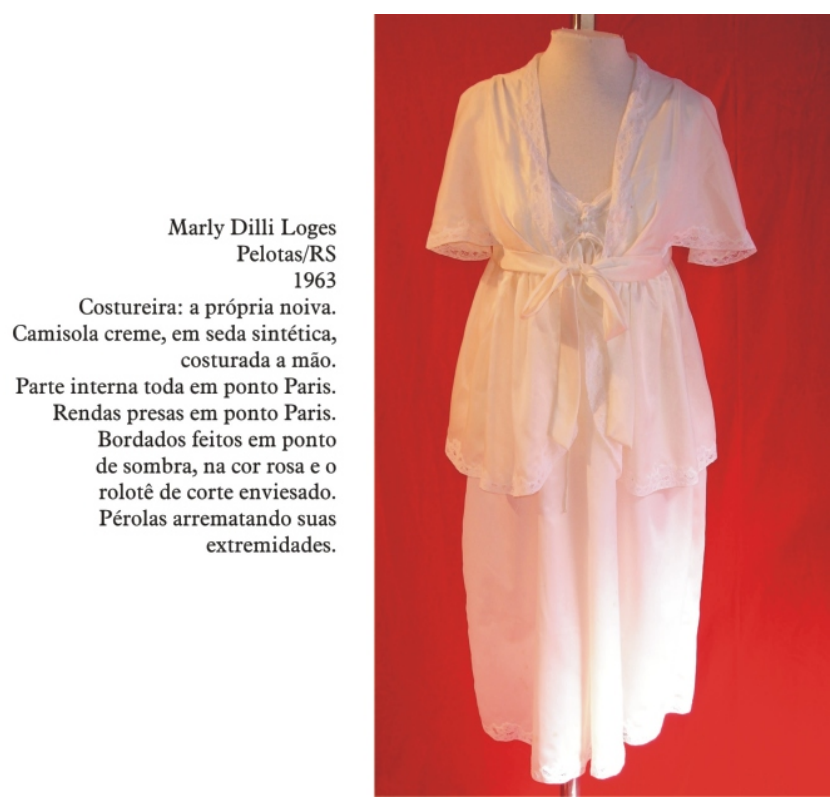

Dona Marly nos relata o seu envolvimento pessoal com a confecção de sua camisola do dia:

A camisola foi feita por mim e toda costurada a mão. $\mathrm{O}$ trabalho foi iniciado mais ou menos meio ano antes do casamento e levei em torno de três meses confeccionando as duas peças: maianita e camisola. $\mathrm{O}$ rolotê foi arrematado com uma pérola em suas pontas. $\mathrm{O}$ tecido utilizado era chamado lingerie ou seda lingerie, mas era uma seda sintética.

A predileção por pontos executados a mão se dava, sobretudo, pelo grande significado atribuído ao objeto. A utilização de pontos a máquina, de certa forma, desferia uma mácula ao tecido, denotando desmazelo da futura dona de casa no referente aos seus assuntos e interesses mais íntimos.

O valor do trabalho a mão pode ser verificado no Manual Singer de Costura, de $1957,{ }^{11}$ que, para persuadir as donas de casa a se utilizarem da máquina de costura para confecção de peças de maior significado simbólico e afetivo, argumentava insistentemente que o uso desse recurso mecânico não depreciaria as peças. 


\section{Figura 4}

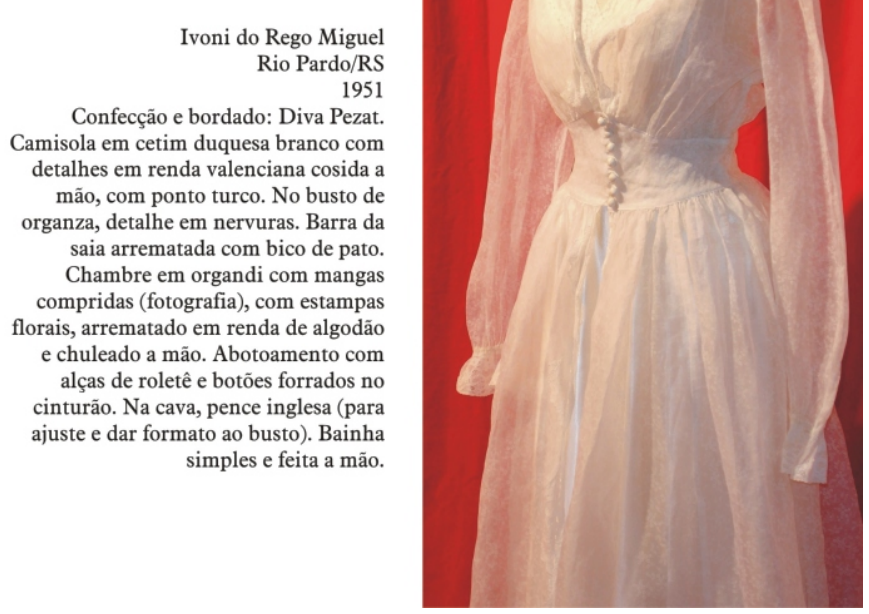

Para aquelas que ainda apresentassem alguma resistência, o mesmo manual sugeria, em último caso, a utilização de pontos manuais sobre o trabalho executado a máquina. Diante do número de argumentos elencados a fim de convencer senhoras a utilizarem pontos a máquina em seus enxovais, pode-se constatar que, ainda na metade do século XX, era dada grande atenção aos trabalhos manuais. E, sobretudo, era notória a resistência, por parte das mulheres, em inserir pontos a máquina em vestes especiais, como se o trabalho mecânico profanasse o sagrado e desmerecesse a habilidade das mãos delicadas. Bordar e costurar eram, ainda, habilidades valorizadas, principalmente no tocante à mulher dedicada ao lar. De certo modo, essa valorização do bordar e costurar a mão, e em casa, pode ser considerada uma sorte de resiliência social da sociedade pré-industrial, em que o fabrico doméstico e manual das peças do vestuário estava enraizado como uma ocupação feminina, em que o conhecimento dos tecidos e o saber fazer associado era um domínio cotidiano das mulheres. Engendrava sua sociabilidade doméstica e sua ocupação do tempo. Como ressalta Anne Hollander (1996: 149-150), até meados do século XIX

não havia virtualmente a moda de roupas prontas para as mulheres, apenas outras indumentárias e adornos para a cabeça. $\mathrm{O}$ que não era feito sob medida era feito em casa ou então era de segunda 
mão. De fato as mulheres ricas ou pobres sabiam como costurar ou entendiam de costura - um número grande delas ganhava a vida com isto. [...] Para as mulheres, mas não para os homens que as observavam, suas roupas não eram nenhum mistério criado em lugares desconhecidos por processos não-familiares. As roupas e sua confecção, para a maioria das mulheres, eram uma questão doméstica íntima. Elas poderiam costurar interminavelmente para o lar, fazendo o acabamento de lençóis e toalhas e confeccionando roupas de baixo junto com todos os outros tipos de costura. $\mathrm{O}$ bordado era feito na presença de visitas; todo o resto era trabalho comum de uma mulher.

Essa atenção aos pontos manuais decorria, ainda, da delicadeza que os mesmos conferiam à peça. Desde o século XIX até as primeiras décadas do século XX, um dos tecidos mais utilizados para as peças íntimas foi o nanzuk, espécie de cambraia de algodão mais encorpada. A partir da década de 1930, caem na preferência a seda e o cetim (Figura 4) para a confecção de camisolas (O'Hara, 1992: 194). A camisola e robe de chambre da senhora Ivoni do Rego Miguel, peças finamente confeccionas pela renomada costureira rio-pardense Diva Pezat, exemplificam o uso do cetim.

Figura 5
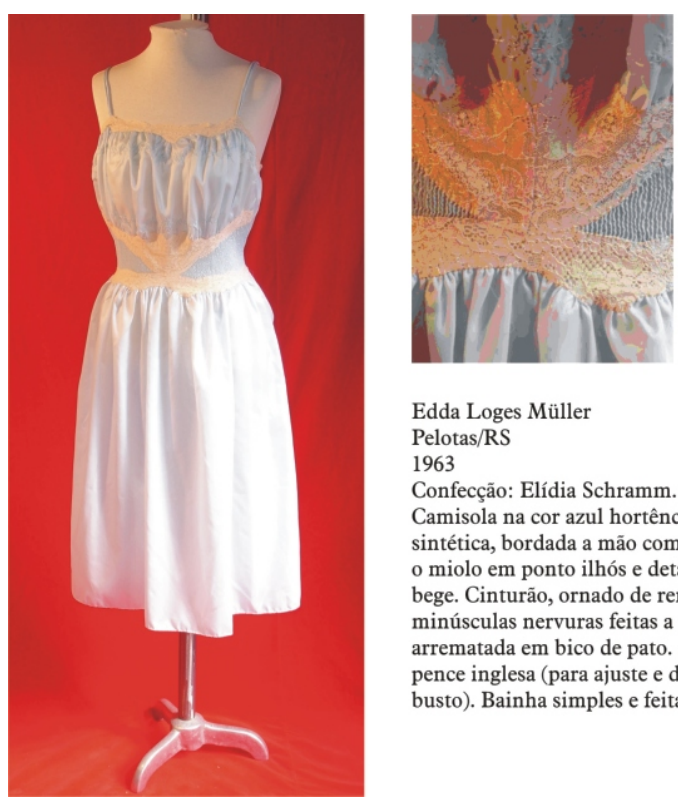

Edda Loges Müller

Pelotas/RS

1963

Confecção: Elídia Schramm.

Camisola na cor azul hortência, em seda

sintética, bordada a mão com flores que possuem

o miolo em ponto ilhós e detalhes em renda

bege. Cinturão, ornado de renda, composto por

minúsculas nervuras feitas a mão. Barra da saia arrematada em bico de pato. cinturão. Na cava, pence inglesa (para ajuste e dar formato ao busto). Bainha simples e feita a mão. 
As variações das cores partem do branco puro e transitam por entre nuanças de crus, rosas e beges, evocando respectivamente a ideia de pureza, feminilidade e castidade. Na escolha da linha e do bordado a ser executado, procurava-se harmonizar o conjunto. Aplicações em renda, entremeadas em tecido, figuravam entre bordados em pontos cheios, richelieu (crivo), sombra, rococó. Chuleados, ponto Paris e caseados arrematavam estas peças (cf. Figura 3).

A camisola da senhora Edda Loges Müller, confeccionada pela costureira Elídia Schramm, combina bordados a mão e ornados de rendas com primorosas minúcias, que podem ser observados em detalhe (Figura 5 e detalhe).

Para a escolha do modelo, bordadeiras apresentavam como sugestão riscos com motivos variados, em papéis de seda, ao gosto da cliente. Figurinos exibiam modelos de pala, império, acinturados ou com cintura deslocada para o quadril. As costureiras cortavam as saias em godê, evasé ou franzidas. Com a introdução do nylon nas roupas íntimas, a partir de meados do século $\mathrm{XX}$, foram produzidas camisolas e rendas nesse material (Figura 6). Mas eram outros tempos, em que a virtude do trabalho manual cede lugar à tecnologia do tecido sintético - e com essas mudanças, iam-se já os tempos da camisola do dia.

\section{Figura 6}

Zélia Dutra Lisboa Sobral Soares Arroio Grande/RS

Confecção: Valisére. Camisola em nylon cereja com corte império. Renda de nylon da mesma cor arremata decote e barra da saia da camisola. Robe de chambre possui gola, punhos e bainha ornados com a mesma renda. Botões de fita de cetim enrolados em

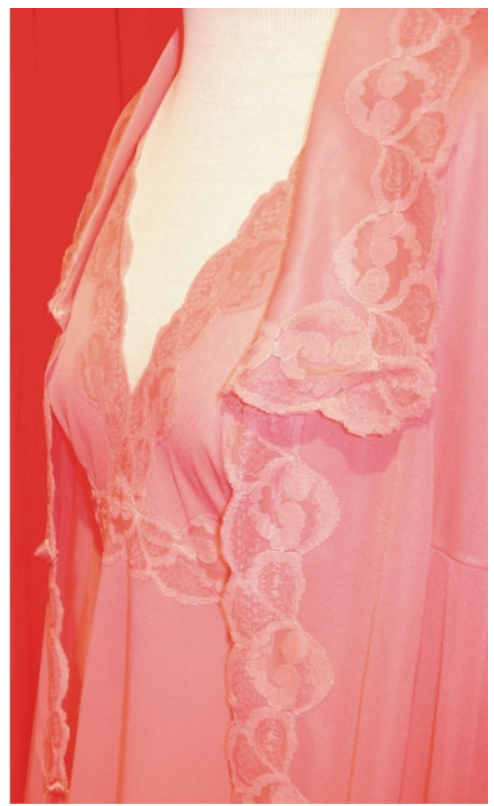


As escolhas técnicas para a confecção da camisola do dia faziam convergir sedução e pudicícia, na medida em que a cor branca imaculada, aceitando-se discreta variação em tons de creme, sugeria a pureza da noiva, simbolismo acentuado pelo uso de outras tonalidades nas camisolas reservadas às noites ulteriores à primeira.

\section{A “cultura material nupcial" e seus simbolismos: ingenuidade, pureza e virtude}

O enlace matrimonial - religioso ou civil, cristão ou pagão - constitui um dos mais importantes rituais de passagem estruturantes da vida em sociedade, sendo recorrente em grande número de sociedades humanas ao longo da história. Por meio do casamento, renova-se a célula familiar - nuclear ou extensa, a família é sempre a unidade social básica. Nas sociedades patriarcais, garante a criação de filhos legítimos para herdar os bens paternos e assegurar a preservação da riqueza, da propriedade. Mais que isso, ao dar sequência à família, o ritual do casamento coloca em relação o presente dos vivos, o passados dos ancestrais e o futuro dos descendentes. Em muitas sociedades, ele assegura e constantemente ressignifica o ancoramento do homem no tempo.

Nesse ritual, cruzam-se as expectativas que a sociedade projeta sobre o homem e sobre a mulher. Todavia, é sobre o gênero feminino que recai a carga simbólica mais densa, uma vez que o espaço da casa, cenário da vida matrimonial, costuma ser o espaço feminino por excelência, em várias culturas e em vários momentos da história. Mais que isso, sobre a mulher é depositada a cobrança de pureza, configurada no preceito da virgindade, garantia de legitimidade da descendência.

A cerimônia de casamento, portanto, constitui um complexo de significações, cujas nuances se fazem presentes em pequenos detalhes, de ordem tangível e intangível. Assim, os simbolismos sociais do casamento, nas diferentes culturas, podem ser descortinados na observação de pormenores ritualísticos que compõem as núpcias, assim como em aspectos da "cultura material matrimonial".

Desde a Antiguidade, o simbolismo do ritual manifesta-se em pequenas coisas, que muito nos revelam sobre o lugar da mulher e do matrimônio na sociedade. Boa parte do Código de Hamurábi, da antiga Babilônia, que constitui um dos códigos de lei mais antigos da humanidade, dedica-se a regulamentar a instituição do matrimônio, revelando o quanto a mesma era entendida como fundamental na organização da antiga sociedade mesopotâmica. Inúmeras leis regravam situações como o dote, a viuvez, a tutela feminina, a herança e o adultério 
(Bouzon, 2000). A iconografia do antigo Egito revela-nos o requinte e o preparo da indumentária e do tocador das damas nas festas de casamento, superados apenas, naquela sociedade, pelos banquetes funerários, principal ritual de passagem egípcio (Brancaglion, 1999; Noblecourt, 1994).

$\mathrm{Na}$ Grécia antiga, as festividades iniciavam com as oferendas pré-nupciais e incluíam os brinquedos da menina-noiva e seus cachos de cabelo, os quais eram oferecidos a divindades relacionadas ao casamento, como Hera ou a ninfa do amor (Cerqueira, 2010: 126-127). Marcava-se, assim, a despedida da infância, anunciando a transição para o futuro papel de mãe-esposa, papel que era, para ela, um grande mistério, algo completamente desconhecido. Heródoto atesta o costume deliano das meninas de deixarem um cacho de cabelos junto ao templo de Artemis (Heródoto, História, IV. 34. cf. Eurípides, Ifigênia em Áulis).

No mundo cristão ocidental moderno, o enxoval constituiu um dos componentes de maior destaque na "cultura material matrimonial", sendo cada um dos seus itens prenhe de significações, portador de tradições do saber fazer e tradições de práticas rituais. Os conceitos de impureza e pureza repercutiam sobre a escolha das cores e tecidos das peças.

Entre os descendentes de imigrantes pomeranos da região sul do Rio Grande do Sul, a memória social reporta ao curioso costume da troca da roupa dos noivos ao longo das festividades: em determinado momento, os noivos iam para o quarto, para retirarem a roupa branca, e a noiva passava a vestir, nesse momento, um vestido escuro (Maltzahn, 2007).

Na sociedade brasileira do século XX, sobretudo nas décadas que sucederam a Segunda Grande Guerra Mundial, nos anos 1940 e 1950, quando ocorrera uma grande valorização da instituição matrimonial, houve um renovado interesse social muito grande pelo enxoval da noiva, interesse que se esvai a partir dos anos 1960 (Teixeira, 2004: 286).

Esse reforço da instituição matrimonial e do ritual nupcial foi uma tendência bastante pronunciada em todo o Ocidente. Numa edição destinada a noivas, da revista Manequim, de 1962, foram publicados os dez mandamentos da noiva moderna, em que se enumeram algumas dicas sobre o preparatório da noiva, incluindo, no seu décimo mandamento, a seguinte recomendação, que sugere uma mística dos objetos: "uma noiva anglo-saxônica deve usar no dia do seu casamento, algo de velho, algo de novo, algo de azul, algo de emprestado".

Neste contexto, consolidou-se, em um ambiente sobejamente feminino, toda uma cultura requintada de produção das peças que compunham esse enxoval. Entre tantas peças da intimidade do futuro casal, destaca-se aquela a ser usada na noite de núpcias, a camisola do dia. Ela integrava o chamado terno do dia, composto pela saia, camisola, maianita e chambre. Outras peças do enxoval compunham ainda a dimensão da "cultura material" do ritual de núpcias, tais como 
o lençol do dia, e as camisolas do segundo e do terceiro dias, amarelinhas ou rosa, diferentemente da camisola do dia (isto é, da primeira noite), a qual deveria ser branca, como metáfora da virgindade.

A camisola do dia carrega consigo toda uma série de projeções que a sociedade lançava sobre as mulheres - a pureza, a virgindade... -, além das projeções que as mulheres jogavam sobre si mesmas. A camisola do dia separava a menina-noiva do desconhecido - a vida de esposa-mãe, sobre a qual sabia tão pouco quanto as meninas da Grécia antiga, que ofereciam seus cachos à deusa Artemis. Elas tinham seu futuro definido por meio de um contrato oral estabelecido entre o pai da noiva, de um lado, e o pai do noivo e o noivo, de outro (Cavalier, 1996; Reeder, 1995; Cerqueira, 2010).

Desse modo, essa veste especial carrega consigo a profundidade da psicologia histórica de meninas e moças de outrora, hoje mães e avós, algumas já falecidas, outras ainda vivas. Na memória social, a camisola traz consigo um contraditório conjunto de expectativas, frustrações, alegrias, desilusões. São memórias femininas, íntimas, fragmentos de uma sociedade patriarcal cuja força se fez presente até meados do século passado.

Nessa medida, procuraremos analisar a significação da camisola do dia à luz da memória evocada por mulheres que, através dessas peças, recordam-se de momentos íntimos de sua juventude, evocando sentimentos controversos e por vezes constrangedores nas descendentes que conservam carinhosamente essas delicadas peças em seus pequenos museus familiares.

Por se tratar de um passado recente, o respeito à intimidade familiar, de senhoras, mães, avós e netas, impõe-nos que o assunto seja tratado de forma anônima, abordagem que se legitima pelo fato dessa instituição - a camisola do dia nos remeter a representações de época, tratando-se, portanto, de memórias pessoais, familiares, que refletem memórias coletivas. Assim, seguindo metodologia etnográfica, visando a preservar a intimidade das depoentes e para despersonalizar as narrativas, caracterizando-as como visão de mundo de uma época, os nomes das depoentes foram substituídos por nomes de fantasia (apenas prenomes), arbitrários, sem qualquer relação com as pessoas que foram entrevistadas e deram acesso às camisolas do dia para estudo e exposição.

\section{Memórias orais: usos e expectativas, inseguranças e frustrações}

Derivada da camisa íntima ou corpete, a camisola foi introduzida no vestuário feminino no princípio do século XIX. Inicialmente, foi utilizada entre o espartilho e o vestido. Entretanto, tão logo as mulheres abandonaram o espartilho no começo do século XX, passou a ser utilizada diretamente sobre a pele. 
Hoje, poucas pessoas detêm o conhecimento para a produção dessa peça, que exigia grande habilidade manual. Há poucas décadas, o saber fazer da camisola do dia era repassado de geração a geração, dentro das próprias famílias e, posteriormente, no ensino para moças, tornando-se parte da educação e, consecutivamente, do universo feminino.

$\mathrm{Na}$ cidade de Pelotas, muitos enxovais foram feitos pela costureira Terezinha Centeno. Em cidades como Porto Alegre eram contratados os serviços das chamadas bordadeiras especiais de enxoval, como nos narra Natália. No entanto, o mais valorizado era que as peças fossem confeccionadas por pessoas do universo pessoal de relação da noiva, parentes ou amigas da família. Mesmo quando se contratavam os serviços de costureiras ou bordadeiras para as peças mais finas do enxoval, informa-nos Natália, mulheres da família, prendadas na arte da costura, sobretudo tias, colaboravam confeccionando as peças mais comuns do enxoval, fazendo muito uso da cambraia. A regra era evitar o uso da máquina de costura. O valor estava na delicadeza do trabalho manual. Era aceitável o uso da máquina para peças de menor simbolismo, como os lençóis e toalhas:

No ano de 51, ainda era hábito a noiva levar um enxoval completo. Roupas de cama, mesa e banho, acompanhavam a camisola do dia. O enxoval da noiva foi adquirido por sua mãe. As peças, como lençóis e toalhas grandes, foram bordadas à máquina por uma prima da noiva. As demais peças, como guardanapos e outros acessórios, foram feitos de crochê ou bordados a mão pela própria noiva (Martha).

Como se vê, era valorizada a participação da própria noiva na confecção do enxoval:

A noiva escolheu os tecidos e seus pais pagaram. Constava de um lote de linho que seria para lençóis, colchas, toalhas de mesa, banho e rosto; guard de prato e um lençol de linho branco com uma barra bordada em crivo para noite nupcial. O enxoval foi feito por mim e outras pessoas que bordavam (Heloísa).

Famílias inteiras se envolviam nos bordados e costuras:

A camisola foi bordada pela minha tia, irmã do meu pai. Ela bordou tudo a mão. O enxoval, sei que foi todo bordado a mão pelas minhas tias, irmãs do pai e da mãe. Todas eram excelentes bordadeiras, 
inclusive duas de minhas irmãs herdaram esse talento. (...) Acho que o bordado está muito presente em nossa história. Pena que, hoje, praticamente tudo é feito a máquina... (Renata) (grifo dos Autores).

As memórias da camisola do dia, no entanto, colocam-nos em contato com uma realidade particular, que a diferencia do conjunto do enxoval, o qual inclui peças que visam a acompanhar a intimidade do casal por muitos anos: esta peça, de delicada confecção manual, será usada somente na noite de núpcias.

Visitando o tempo passado através da memória contada em encontros e conversas com algumas senhoras, foi possível desvelar detalhes da primeira noite, aqui apresentados de forma sucinta. Num tempo em que as moças se entregavam virgens aos seus parceiros, com muito pouca ou nenhuma informação, desejos contidos ou mesmo sua inexperiência tornavam cada experiência singular. Algumas experiências envoltas em romantismo, outras traumatizantes ou com desfechos surpreendentes figuram entre as inúmeras narrativas acerca deste objeto. Vale destacar o relato de um grupo de senhoras que comentavam a respeito da primeira noite de uma amiga em comum, que havia preparado uma belíssima camisola do dia: "Coitada [...], ele se jogou em cima dela e rasgou a camisola”.

Essa história sinaliza para um aspecto bastante recorrente nas narrativas: o lado desastrado, cômico, que constitui uma estratégia para tratar, através do humor, das desilusões ou do peso que o simbolismo da camisola do dia exerceu e exerce sobre mulheres da sociedade brasileira da época, seja ela urbana ou rural.

Esse aspecto está relacionado, com frequência, ao acompanhamento de parentes próximos durante a lua de mel, durante a viagem de ida e volta, mas, por vezes, permanecendo no hotel - em casos extremos, no próprio quarto do casal, quando ocorria a fatalidade de um hotel lotado.

Esta falta de privacidade dos noivos na lua de mel não é um fato isolado nas narrativas da noite de núpcias e da lua de mel. Era muito comum que os noivos viajassem em companhia de tios ou irmãos, lembrando-nos a função da $n a$ moradeira, móvel típico do século XIX e início do século XX, no qual os noivos se sentavam, podendo conversar, enquanto uma terceira figura se sentava entre os enamorados, encarregando-se de fiscalizar os nubentes, ao mantê-los devidamente afastados (Figura 7).

Igualmente usual era que uma tia ou outro parente acompanhasse o casal de noivos, antes do casamento, quando saíam em público, como numa ida ao cinema, comprovando aos olhos da sociedade a ausência de proximidade física entre o futuro casal. 
Figura 7

Namoradeira.

Pelotas, Museu Municipal Parque da Baronesa, inv. MMPB n. 0457.

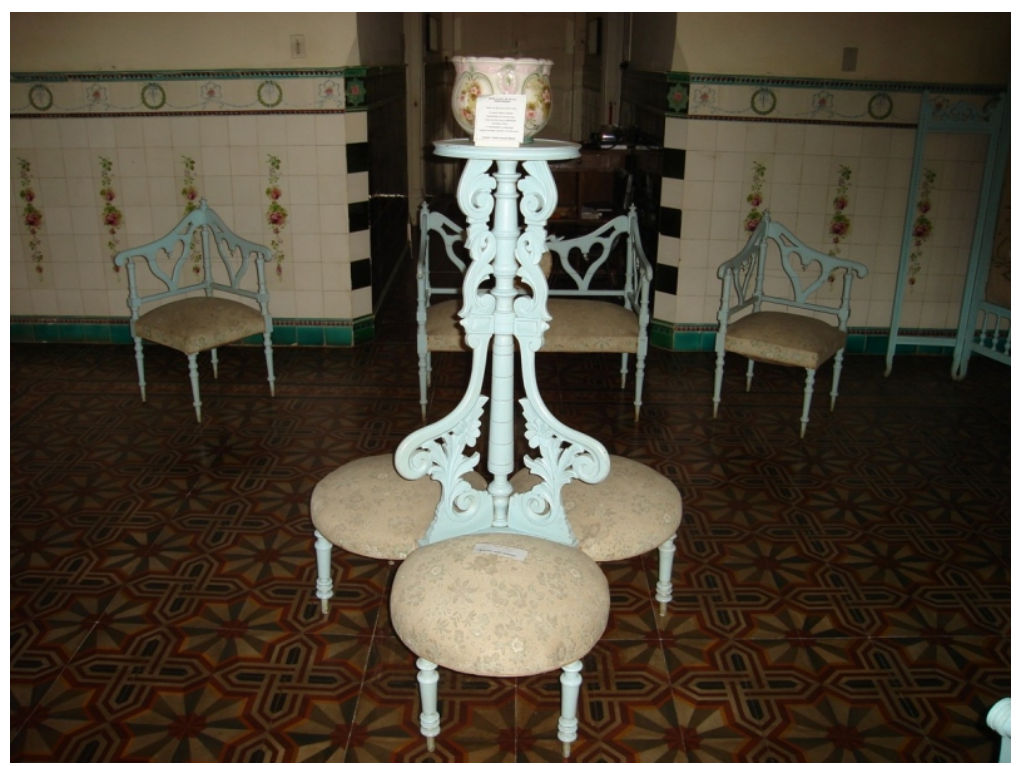

Como contrapartida da pureza e virgindade, esperava-se da noiva uma quase total ignorância com relação aos detalhes da vida sexual de uma esposa. Tratava-se de uma ignorância virtuosa, pois não se esperava de moças de boa índole que conhecessem os detalhes da vida conjugal. Muitas, portanto, casavam-se ainda bastante ingênuas - o pouco que sabiam eram coisas que ouviam, aqui ou ali, entre mulheres da família ou entre colegas de escola. Luiza, filha de Belinha, nos reporta recordações reveladoras sobre a ingenuidade das noivas:

Então ela (minha mãe) amarrou os laços das fitas na altura de cada orelha e falou: - Viste minha filha? Eu estava sentada na cama esperando o noivo. E ele demorou para chegar no quarto por que encontrou um amigo no hotel. Ficaram conversando e ele se atrasou um pouco. Quando o senhor descobriu que papai e mamãe estavam em lua-de-mel, ficou muito envergonhado. Antigamente as mães não diziam as coisas e a gente casava muito crua. As amigas no colégioé que meio falavame conversavam. Tinha-se muito respeito (grifo dos Autores). 
A noite de núpcias suscitava, entre as moças, um conjunto de expectativas, algumas sobre a vida conjugal, outras sobre a vida maternal, mas muitas sobre a própria noite que se esperava ser a mais especial de suas vidas.

A primeira expectativa recaía sobre a própria camisola. Estaria no tamanho certo? Agradaria a seu noivo? E de que forma agradaria sem provocar alguma imagem de vulgaridade. Algumas narrativas orais respondem a essas questões. Martha enfrentou um único contratempo com sua camisola: "ficou comprida, motivo pelo qual o babado da barra da saia precisou ser levantado às pressas no próprio dia do enlace".

Heloísa teria ficado desagradada com o comentário feito por seu esposo, o qual, mesmo querendo elogiá-la, pareceu-lhe sugerir, com suas palavras, algo que contrastava com a auto-imagem de recato - é como se uma simples palavra fosse capaz de macular a imagem de dignidade:

Quando a mãe vestiu a camisola, o pai olhou para ela e perguntou: de onde a senhora veio? Veio de Paris? A noiva não gostou do comentário; contentava-lhe que ele tivesse achado a camisola linda.

As maiores expectativas, no entanto, relacionavam-se à troca amorosa da primeira noite do casal. Em vários casos, porém, a noiva desiludia-se. Nem sempre a tão sonhada lua de mel se concretizava:

O casal, após um jantar a sós no restaurante Normandie, do City Hotel, em Porto Alegre, e haver dado um passeio pelos recantos preferidos da cidade, recolheu-se à sua casa, sem possibilidades de realizar lua de mel.

Às vezes a lua de mel fracassa por fatalidades, como motivos climáticos. Este foi o caso da noite de núpcias de Heloísa, que precisou esperar por mais um dia:

Choveu muito no dia do casório; então, não fomos para nossa casa, pois era distante de nossa cidade, num lugar onde tínhamos uma granja de arroz. A noiva dormiu na casa dos pais e o noivo na casa dos tios. A noite nupcial ocorreu só no dia seguinte.

Alguma fatalidade pode levar à completa frustração quanto ao momento especial, portanto alegre e feliz, que deveria ser a festa e a lua de mel, na qual a camisola do dia constituía a peça principal. O relato de Sônia nos reporta a recorda- 
ção de uma festa privada do brilho, da alegria, em virtude de um sofrimento familiar pela perda recente de um ente querido:

Não tenho uma história, assim, de um grande casamento. Eu e meu noivo éramos pelotenses. Eu estava estudando em Porto Alegre e o noivo morava, do mesmo modo, em outra cidade. [...] Tínhamos muito pouco tempo para casar e esse casamento já tinha sido transferido. Então, marcamos uma data e minha avó morreu poucos dias antes. Faltavam 15 dias para o meu casamento quando ela morreu. Então, aí, o casamento não podia mais ser adiado. [...] foi somente uma missa, de manhã, na igreja principal da cidade. [...] Foi uma coisa muito íntima.

As festividades de casamento, mesmo prenhes de significações que se projetavam sobre a imagem de pureza e dignidade da noiva e do noivo, não possuíam a superprodução dos casamentos modernos. A simplicidade na escolha dos locais retrata essa fase em que o sentimento intimista de fragilidade, de ingenuidade, era respeitado. Como exemplo desse quadro de presumido recato, Eliana nos relata que a recepção do casamento, após a cerimônia na capela da Beneficência Portuguesa, em Pelotas, foi realizada na casa da sogra, posto que, naquela época, não era usual realizar os festejos do casamento em um clube.

Assim, entre os diversos fatores que compunham as significações associadas à camisola do dia, constatamos um jogo instável que fluía entre a dignidade, a intimidade e a ingenuidade. Recato e sedução fluíam por entre gazes, organzas, sedas, rendas, barras e bordados:

O jogo completo, a saia, a camisola, a calcinha e maianita, que ia até a cintura, com o mesmo feitio do chambre, com a mesma renda, seguindo o modelo. A saia, eu lembro-me, era tão bonita, tinha a mesma parte de gaze que tinha no busto, e a renda subia e descia. No formato da renda recortada na barra. A parte mais alta tinha um palmo de altura, mais ou menos. [...] O pijama do noivo era branco, de seda pura (Eliana).

\section{Considerações finais}

Passados os anos, muitas dessas camisolas do dia ficaram guardadas na família, passando, de mãe para filha, quase como um relicário. Hoje, filhas e netas se interessam por conservar estas peças. Muitas vezes, porém, sua preservação se dá 
também através de sua reutilização, por vezes sendo usadas pelas descendentes, filhas, sobrinhas e netas, nas noites de núpcias ou em outras ocasiões especiais.

A camisola do dia constitui-se, portanto, no âmbito da "cultura material matrimonial", em um objeto que nos permite descortinar uma série de simbolismos associados à instituição do casamento em setores da sociedade brasileira das seis primeiras décadas do século XX. Muito mais do que a delicadeza do saber fa$z e r$, importa compreender, nela, na camisola, as expectativas da noiva, com suas ansiedades, dúvidas, inseguranças, frustrações, assim como as alegrias e satisfação da primeira noite do casal, propiciatórias de um bom relacionamento, auspiciosas para a constituição de uma família feliz.

Como monumento cultural, como algo que faz lembrar, ${ }^{12}$ as camisolas $d o$ dia são hoje mais do que um bem patrimonial têxtil. São um testemunho da psicologia feminina engendrada em uma sociedade na qual as relações afetivas e a instituição do casamento seguiam regras que, aos poucos, desde as décadas de 1960 e 1970, se esvaneceram. Regras ditadas não somente pelos interesses de uma sociedade patriarcal, mas, mais que isso, formadas dentro de um imaginário e de uma moralidade enraizados na tradição cristã, remanescentes da Antiguidade, que, até há pouco tempo, impunha a virgindade às moças como condição moral para contrair casamento.

Notas

1. Em seu estudo etnográfico sobre a camisola do dia, Sérgio Teixeira (2004) verificou a existência desse costume em várias regiões do país, sobretudo no Sul, Sudeste e Nordeste, nas quais realizou suas observações de campo. Dada sua abrangência cultural, ele define a camisola do dia como uma verdadeira instituição social brasileira, cuja vigência teria tido início no final do século XIX, estendendo-se até meados do século XX.

2. As fotografias das camisolas foram feitas pelo designer e fotógrafo Mauro Bruschi.

3. Grifos dos autores.

4. Herivelto Martins, carioca nascido em 1912 e falecido em 1992, foi compositor e cantor, tendo mantido relacionamento com a cantora Dalva de Oliveira (19171955). Compôs várias músicas em parceria com David Nasser (1907-1980), jornalista e compositor mineiro, filho de imigrantes libaneses.

5. Grifos dos autores.

6. Nascido em Salvador em 1904, Pedro Wayne mudou-se aos dois anos para o Rio Grande do Sul, para Bagé, onde tornou-se escritor. Faleceu em 1951. Sua obra mais conhecida é o romance Xarqueada, de 1937. Versos Meninósos e a Lua foi o seu primeiro livro de poemas, escrito em 1931, no qual, no poema Primeira Noite, reporta-nos memórias evocativas de suas núp- 
cias com Leopoldina Calo Wayne, ocorridas três anos antes, em 1928. O comentário de Cristina Rosa localiza a envergadura de sua contribuição à cultura gaúcha do século XX: "No contexto da literatura sulrio-grandense, Pedro Wayne (1904-1951) ocupa um lugar especial. Foi adepto de primeira hora do projeto modernista, gestado na São Paulo dos anos 1920 do século passado, e difundido pelas distintas regiões brasileiras ao longo daquela década e dos anos seguintes. Foi também um motivador cultural junto à sua geração e a de então jovens artistas, como os pintores bageenses Danúbio Gonçalves (1925), Glênio Bianchetti (1928) e Glauco Rodrigues (1929), expoentes que, mais adiante, junto a Carlos Scliar (1920-2001), de Santa Maria, e de Vasco Prado (1914-1998), de Uruguaiana, formaram o famoso Clube de Gravura de Porto Alegre que, por volta de 1950, alavancou as artes plásticas no Rio Grande do Sul. Foi igual e plenamente poeta e ficcionista. [...] Assim, não apenas compartilhou o projeto experimentalista adotado por sua geração, como o transportou para a sua linguagem literária, colaborando com a para a renovação da poesia sul-riograndense [...].” (Rosa, 2009: 10).

\section{Grifos dos autores.}

8. A identificação das técnicas e tecidos utilizados contou com a consultoria das professoras Maria Rosane Guidotti Moreira, Nina Rosa Granzotto, Viviane Aquino Zitzke e Ingrid Lopes Binsfeld, que lecionam no curso de moda e estilismo do CAVG/IFES - Pelotas/RS.

\section{Referências bibliográficas}

BOUZON, Emanuel. O Código de Hammurabi. Rio de Janeiro: Vozes, 2000.
9. Como ressalta Harvey (2003:23), “o valor íntimo das roupas fica claro se observarmos, em nós mesmos ou nos outros, o modo como tocamos em nossas roupas. [...] Há uma dinâmica no relacionamento entre as pessoas e suas roupas, e entre as outras pessoas e as roupas delas. As pessoas podem jogar com a ideia de tirar peças de roupa [...] numa espécie de flerte. Quando tirar? Quando abandonar ou manter? Devo mostrar outro lado de mim mesmo? As roupas envolvem num jogo de adivinhações e brincam com as ideias de reivindicar e oferecer".

10. A primeira denominação desta peça foi "corpinho" e recebia enchimento para dar volume aos seios.

11. A Singer publicou manuais de costura e livros de bordados que instruíam sobre a preparação, funcionamento e manejo dos seus distintos modelos de máquinas de costura. Esses manuais ensinavam a reproduzir desenhos para serem bordados a máquina, com diferentes espessuras de linhas e tecidos, além de ensinar nomes usuais de diferentes pontos e sua execução, passo a passo, dos primeiros pontos aos mais elaborados. Alguns continham modelos de roupas ou sugestões para confecção de artigos de decoração e indicavam as linhas e agulhas adequadas por meio de tabelas de pontos por centímetro.

12. Monumento vem da palavra latina monumentum, derivada de moneo ("levar a pensar”); refere-se à lembrança, assim como patrimonium, que carrega o mesmo radical.
BRANCAGLION JR., Antonio. Obanquete

funerário no Egito Antigo, Tebas e Saqqara: 
tumbas privadas do Novo Império (1570- 1293 a.C.). Tese (Doutorado em Arqueologia). Programa de Pós-Graduação em Arqueologia, Universidade de São Paulo, São Paulo, 1999 .

CAVALIER, Odile. Silence et fureur. La femme et le mariage en Grèce. Les Antiquités grecques du Musée de Calvet. Avignon: Fondation Musée Calvet, 1996.

CERQUEIRA, Fábio Vergara. A representação do casamento e do amor matrimonial na cerâmica ática: sentimentos íntimos da mulher ateniense (séc. VI - V a.C.). In: SILVA, Úrsula Rosa; MICHELON, Francisca Ferreira \& SENNA, Nádia da Cruz. Imagens tangenciadas no tempo. Estudos sobre representações femininas. Pelotas: Editora Universitária - UFPel, 2010, p. 119-159.

et alii. Programa Memoriar: sensibilização de jovens para a diversidade identitária por meio da educação patrimonial. In: Anais do V Encontro do Núcleo Regional Sul da Sociedade de Arqueologia Brasileira-SAB/Sul, de 20 a 23/11/2006, Rio Grande, RS. São Leopoldo: Editora da Unisinos, 2006, p. 1-8.

FUNARI, Pedro Paulo. Arqueologia. São Paulo: Editora Ática, 1988.

Os historiadores e a cultura material. In: PINSKY, Carla Bassanezi (org.). Fontes históricas. São Paulo: Contexto, 2005, p. 81-110.

\& PELEGRINI, Sandra. Patrimônio Cultural Imaterial. São Paulo, Brasiliense, 2007.

GRUNBERG, Evelina. Educação Patrimonial: Utilização dos bens culturais como recursos educacionais. Cadernos do CEOM, Chapecó, SC, Argos, nº 12,2000, p. 159-180.

HARVEY, John. Homens de preto. São Paulo: Unesp, 2003.
HOLLANDER, Anne. O sexo e as roupas: a evolução do traje moderno. Rio de Janeiro: Rocco, 1996.

LAVER, James. A roupa e a moda: uma história concisa. São Paulo: Companhia das Letras, 1989.

MALTZAHN, Gislaine Maria. "Um casalzinho novo para a comunidade": etnografia de um casamento pomerano, São Lourenço do Sul $(R S)$. Monografia de conclusão de curso de licenciatura em História, Universidade Federal de Pelotas, Pelotas, 2007.

MÁRQUEZ, Gabriel García. $A$ revoada: o enterro do diabo. Rio de Janeiro: Record, 1999.

MUNIZ, Silvana Cristina Oliveira. Núcleo Pedrinhas - história e imagem. In: FUNARI, Pedro Paulo Abreu. Cultura material e arqueologia histórica. Campinas: Unicamp, Instituto de Filosofia e Ciências Humanas, 1998, p. 221-250.

NOBLECOURT, Christiane Desroches. $A$ mulher no tempo dos faraós. Campinas: Papirus, 1994.

O'HARA, Georgina. Enciclopédia da moda: de 1840 à década de 80. São Paulo: Companhia das Letras, 1992.

ORSER Jr., Charles E. Introducción a la Arqueología Histórica. Buenos Aires: Asociación Amigos del Instituto Nacional de Antropología, 2000.

PEIXOTO, Luciana da Silva. Arqueologia e patrimônio: o urbano na ótica da cultura material. In: CERQUEIRA, Fábio Vergara; GUTIERREZ, Ester Judite Bendjouya; SANTOS, Denise Ondina Marroni dos \& MELO, Alan Dutra de (orgs.) Educação patrimonial: perspectivas multidisciplinares. Pelotas: Instituto de Memória e Patrimônio, 2008, p. 87-90.

RADLEY, Alan. Artefactos, memoria y sentido del pasado. In: MIDDLETON, David.; EDWARD, Derek. (orgs.) $\mathrm{Me}$ - 
moria compartida: la naturaleza social del recuerdo y del olvido. Buenos Aires: Paidos, 1992, p. 63-76

REEDER, Elen . D. (org.) Pandora. Women in Classical Greece. Baltimore, Maryland: The Walters Gallery of Art; Princeton/New Jersey: Princeton University Press, 1995.

ROSA, Cristina. Um alfabeto à parte: biobibliografia de Pedro Rubens de Freitas Weyne, o Pedro Wayne. Pelotas: Editora e Gráfica Universitária Ufpel, 2009.

SANTOS, Denise Ondina Marroni dos. Estudo sobre o vestuário e sociedade a partir do acervo têxtil do Museu da Baronesa (Pelo-
tas/RS). Dissertação (Mestrado em Memória Social e Patrimônio Cultural) - Programa de Pós-Graduação em Memória Social e Patrimônio Cultural, Universidade Federal de Pelotas, Pelotas, 2009.

SILVEIRA, Cátia Luciane Silva. O cheiro do barro queimado. Memórias das olarias do Rio Piratini (Pedro Osório e Cerrito/RS). Monografia de conclusão do curso de especialização em Memória, Identidade e Cultura Material, Universidade Federal de Pelotas, Pelotas, 2008.

TEIXEIRA, Sérgio. A camisola do dia e o divino conteúdo. Horizontes Antropológicos, $\mathrm{n}^{\mathrm{o}} 22,2004$, p. 285-328.

\section{Resumo}

O presente artigo tem como objeto a camisola do dia, peça do enxoval da noiva feita exclusivamente para a noite de núpcias, usada entre finais do século XIX e meados do século XX. Consideramos, na qualidade de um bem patrimonial têxtil, que é um dos componentes centrais da "cultura material nupcial", carregando consigo um simbolismo associado ao lugar da mulher e do casamento na sociedade cristã moderna ocidental. Nossa atenção volta-se tanto para o saber fazer (a técnica do bordado), quanto para as memórias associadas. Procuramos entender a sua dimensão imaterial, para desvendarmos a rede de significados que a envolve.

Palavras-chave: vestuário; casamento; cultura material; oralidade; patrimônio cultural; memória social.

\footnotetext{
Abstract

The goal of this article is to study the "camisola do dia" (wedding day nightdress), a piece of the bride's trousseau made especially for the wedding night, used from the late nineteenth century to the middle of the twentieth century. As a textile cultural good, we consider it one of the central components of the "wedding material culture", which carries a symbolism linked with the place of women and marriage in modern occidental Christian society. Our attention is turned both to the know-how (the embroidery technique) and to social memories. We seek to understand its immaterial dimension to reveal the net of meanings that surround it.
} 
Key words: clothing; wedding; material culture; orality; cultural heritage; social memory.

\section{Résumé}

L'objectif de cet article est d'étudier la "camisola do dia" (robe de nuit des noces), pièce du trousseau de la fiancée, confectionnée spécialement pour la première nuit des noces, utilisée dès la fin du XIXe siècle jusqu'à la moitié du XXe siècle. En tant que bien culturel typique du patrimoine culturel textile, on la considère un des éléments centrales de la "culture matérielle matrimoniale", qui porte avec soi un symbolisme associé au lieu de la femme et du mariage dans la société chrétienne occidentale. Notre attention est tournée vers le savoir-faire (la technique de broderie) et les mémoires sociales. Nous voulons comprendre sa dimension immatérielle, pour dévoiler le réseau des significations qui l'entourent. Mots-clés: vêtements; mariage; culture matérielle; oralité; patrimoine culturel; mémoire. 